\title{
October 2019 Sediment Disaster in the Tohoku Region owing to Typhoon No. 19 (Tyhpoon Hagibis)
}

\author{
Michiya IRASAWA ${ }^{1}$, Takashi KOI ${ }^{2}$, Ching-Ying TSOU ${ }^{3}$, Nobuaki KATO ${ }^{4}$, \\ Shinjiro MATSUO ${ }^{5}$, Mizuho ARAI ${ }^{6}$, Masahiro KAIBORI ${ }^{7}$, Takashi YAMADA ${ }^{8}$, \\ Mio KASAI ${ }^{8}$, Taeko WAKAHARA ${ }^{9}$, Daisuke HIGAKI ${ }^{5}$, Hajime IKEDA ${ }^{5}$, \\ Yoshiharu ISHIKAWA ${ }^{6}$, Kenichi ARAI ${ }^{6}$, Shinji HIROSE ${ }^{10}$, Tatsuya SATO ${ }^{10}$, \\ Hideki KAWABATA ${ }^{10}$, Manabu KOUBU ${ }^{10}$, Satoshi NIWA 10, Kazuhiro SUGAWARA ${ }^{11}$, \\ Hiroyuki MATSUSAKA ${ }^{11}$, Nobuyuki TADA ${ }^{12}$ and Toshiyuki KON ${ }^{13}$ \\ ${ }^{1}$ Faculty of Agriculture, Iwate University (3-18-8 Ueda, Morioka, Iwate 020-8550, Japan) \\ E-mail : irasawa@iwate-u.ac.jp \\ 2 Center for Natural Hazards Research, Hokkaido University (Kita 9 Nishi 9 Kita-Ku, Sapporo, Hokkaido 060-8589, Japan) \\ ${ }^{3}$ Faculty of Agriculture and Life Science, Hirosaki University (3 Bunkyo-cho, Hirosaki, Aomori 036-8561, Japan) \\ ${ }^{4}$ Faculty of Urban Management, Fukuyama City University (2-19-1 Minato-Machi, Fukuyama City, Hiroshima 721-0964, Japan) \\ ${ }^{5}$ Nippon Koei Co., Ltd. (3-1-11, Kokubuncho, Sendai Aoba-ku, Miyagi, Japan) \\ 6 Asia Air Survey Co., Ltd. (1-4-28, Ichibancho, Sendai Aoba-ku, Miyagi, Japan) \\ ${ }^{7}$ Faculty of Integrated Arts and Sciences, Hiroshima University (1-7-1 Kagamiyama, Higashi-Hiroshima City, Hiroshima 739-8521, Japan) \\ ${ }^{8}$ Graduate School of Agriculture, Hokkaido University (Kita 9 Nishi 9 Kita-Ku, Sapporo, Hokkaido 060-8589, Japan) \\ ${ }^{9}$ Faculty of Agriculture, Tokyo University of Technology and Agriculture (3-5-8 Saiwai-cho, Fuchu-shi, Tokyo 183-0052, Japan) \\ 10 Japan Conservation Engineers Co., Ltd. (3-15-17, Chuodori, Morioka, Iwate, Japan) \\ ${ }^{11}$ PASCO Corporation (205-1, Nakakecho, Sendai Miyagino-ku, Miyagi, Japan) \\ 12 TAC Engineering Co., Ltd. (2-3-202, Tsushida Nishi, Morioka, Iwate, Japan) \\ ${ }^{13}$ Aomori Pref. (1-1-1, Nagashima, Aomori, Japan)
}

\begin{abstract}
Large and powerful Typhoon No. 19 (Typhoon Hagibis) made landfall on the Izu Peninsula on 12 th October 2019, and it brought widespread and record-breaking torrential rain across Japan, especially in Eastern Japan. Emergency warning was issued in Tokyo and 12 prefectures, and many slope failures and debris flows were caused. It marked the largest number of sediment disaster occurrences by a typhoon since 1982 that the statistics have been started to be recorded. 952 sediment disasters were caused by the typhoon (as of 24 th December 2019), and 16 people were killed and one person is missing. In Tohoku region, most disasters happened in Iwate, Miyagi, and Fukushima prefectures. From 1:00 am, 12 th October to $12: 00$ am, 13 th October (two days) total precipitation (observed by AMeDAS of Japan Meteorological Agency) was $594 \mathrm{~mm}$ in Hippo, Marumori-machi, Miyagi prefecture, and $466.5 \mathrm{~mm}$ in Fudai, Iwate prefecture. From the above, Japan Society of Erosion Control Engineering organized "Emergency investigation team for the sediment disasters in Tohoku region caused by Typhoon No. 192019" and performed the investigation for three times. The survey results have been published with the title "Sediment disasters caused by Typhoon Hagibis on October, 2019 in Tohoku region" to the Journal of Japan Society of Erosion Control Engineering, volume 72, No. 6, in 2020 (in Japanese, with English Abstract). This paper provides, as part of a brief summary of these findings.
\end{abstract}

Key words : sediment discharge, sediment disaster, shallow landslide, surface runoff, woody debris

\section{INTRODUCTION}

The large Typhoon No. 19 (Typhoon Hagibis) hit the Izu Peninsula with great force on October 12, 2019, causing record heavy rainfall over a wide area, mainly in eastern Japan. Heavy rainfall warnings were announced in Tokyo and 12 prefectures; there were numerous slope collapses and debris flows and the largest number of typhoon-related landslides since the beginning of recording the statistics in 1982. The typhoon caused 952 sediment disasters (as of December 24, 2019), with 16 people dead and 1 person missing. Rainfall was concentrated in Iwate, Miyagi, and Fukushima Prefectures in the Tohoku 
region. According to the Japan Meteorological Agency Automated Meteorological Data Acquisition System (AMeDAS), the cumulative rainfall from 0 am on October 12 to $12 \mathrm{pm}$ on October 13 (two days) was $594 \mathrm{~mm}$ at the Fuchu station in Marumori Town, Miyagi Prefecture and $466.5 \mathrm{~mm}$ at the Fudai station in Iwate Prefecture. Based on these records, the Japan Society of Erosion Control Engineering established the 2019 Typhoon No. 19 Sediment Disaster Emergency Investigation Team for the Tohoku region and conducted the surveys three times. This paper provides a brief summary of the findings [c.f. Irasawa et al. (2020)] that observed in the Shirahama district in Miyako City, Iwate Prefecture, and the Mawakura area and Shinkawa basin in Marumori Town, Miyagi Prefecture (Fig. 1).

\section{OVERVIEW OF SURVEY LOCATIONS}

The sites required urgent investigation were selected in advance from the sediment-related disaster locations [Ministry of Land, Infrastructure, Transport and Tourism, 2019 ; Japan Meteorological Agency, 2020]. The selected sites were identified by referring to aerial photographs captured immediately after the disaster by the Tohoku Regional Bureau of the Ministry of Land, Infrastructure, Transport and Tourism and by Iwate and Miyagi Prefectures.

The survey was conducted for 6 days : November 2, 3, 9, 10, 30 and December 1 in 2019. In the Kitakami Mountains, the Paleozoic and Mesozoic strata are widely distributed as a whole, and granite intrusions are found in some parts [Irasawa et al., 2017]. The Sanriku coastal area of Iwate Prefecture, where this
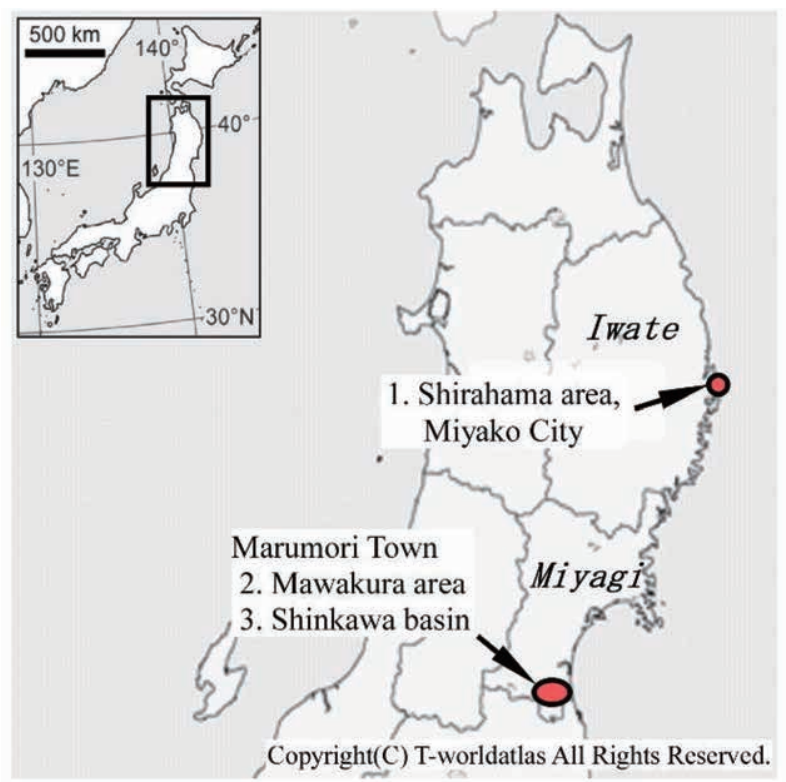

Fig.1 Locations of the study areas study was conducted, comprises Mesozoic accretionary complexes (cherts, slate, etc.) and Kitakami granites. Marumori Town, Miyagi Prefecture, cities of Soma and Minamisoma, and Fukushima Prefecture are located on the Kitakami granites of the Early Cretaceous period (K 1) and the Abukuma granites to the west. Miocene basalt is also intrusive into that area.

\section{RAINFALL OVERVIEW}

Typhoon No. 19 in 2019 rapidly developed and became a violent typhoon shortly after its appearance in the sea to the south of Minamitorishima Island. Thereafter, it maintained a strong force without significantly weakening until landing. Moreover, after landing in Shizuoka Prefecture with a strong force, it maintained the strong force as it passed through the Kanto Koshin and Tohoku regions (Fig. 2). The total rainfall from October 10 to 13 reached $1000 \mathrm{~mm}$ in Hakone Town, Kanagawa Prefecture and exceeded 500 $\mathrm{mm}$ at 17 AMeDAS sites, mainly in eastern Japan. With the typhoon, heavy rains were recorded in a wide area, particularly in eastern Japan, and a special heavy rain warning was issued in 13 prefectures. This rainfall ranked the largest in the history of observation of 12hour accumulated rainfall at 120 sites and 24-hour accumulated rainfall at 103 sites. At the AMeDAS locations in northern and eastern Japan on October 12 (with 613 points available for comparison since 1982), the total amount of daily rainfall observed was the highest in the history of observation (Fig. 3). In addition to widespread flooding of rivers, sediment disasters and inundation damage occurred owing to effects of this heavy rain.

In the Town of Marumori, Miyagi Prefecture, which is located in the Abukuma River basin, an extremely heavy rainfall was recorded. Approximately 10-60-mm rainfall occurred within 1 hour of continuous rainfall on the afternoon of October 12 ; furthermore, 400-mm

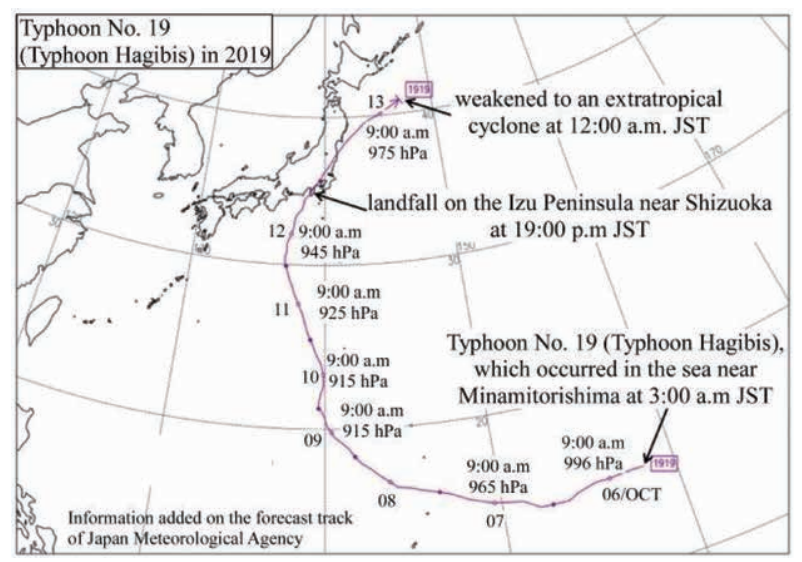

Fig.2 Path of Typhoon No. 19 (Typhoon Hagibis) [Japan Meteorological Agency, 2020] 


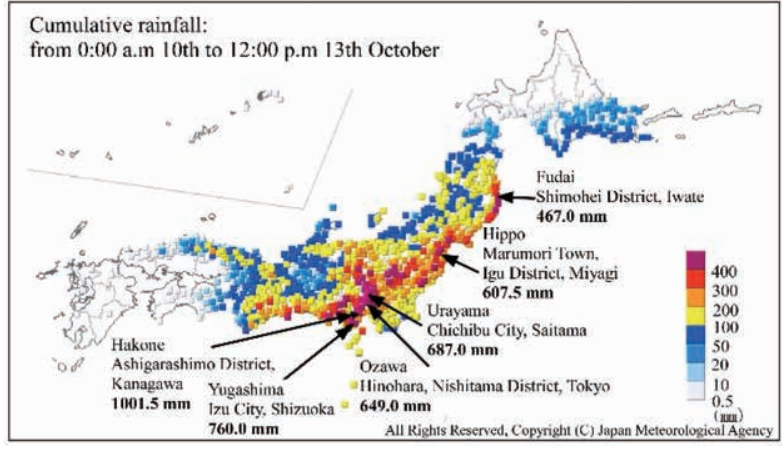

Fig.3 Accumulated rainfall of Radar-AMeDAS grid point value of Typhoon Hagibis (1919)[Japan Meteorological Agency, 2020]

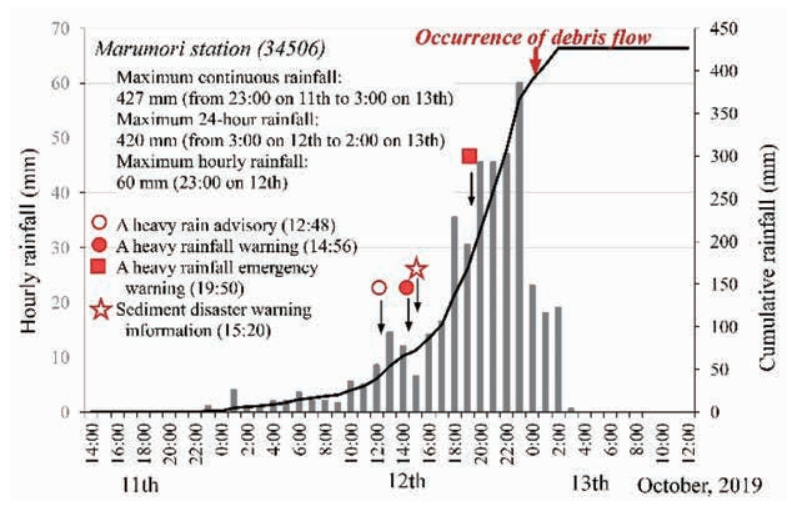

Fig.4 Hourly and accumulated rainfall observed at Marumori station (34506) (data from Japan Meteorological Agency, 2020 ; occurrence of debris flow according to eyewitness accounts)

rainfall occurred in approximately 12 hours, and this 12-hour rainfall set a record (Fig. 4). The Abukuma River basin was assumed to have already been subjected to heavy rain because of frontal and topographic rainfall before the typhoon approached in places such as the upper reaches of the Abukuma River (north of Sakai, Tochigi Prefecture) and the Town of Marumori, Miyagi Prefecture. On the coast of Iwate Prefecture, heavy rainfall occurred even in areas north of the heavy frontal rainfall region (Fig. 3). In this region, a large amount of water vapor was assumed to have flowed into the area because of the northeast wind associated with the typhoon's approach and updraft formation owing to the topography and other factors, which in turn led to heavy rainfall, particularly in coastal areas.

\section{DISASTER SITUATIONS IN EACH AREAS}

\subsection{Shirahama district, Miyako City, Iwate Prefecture}

The Shirahama district is located in the northern part of the Shigemo Peninsula in the city of Miyako. Houses were damaged because of sediment and driftwood from Shirahama River flowing from east to west (hereafter referred to as 'main river') and from a mountain stream flowing from the south (hereafter referred to as 'left tributary') (Fig. 5a). The basin area at the estuary mouth was approximately $2.8 \mathrm{~km}^{2}$; the upstream area and average riverbed gradient at the affected houses were approximately $1.1 \mathrm{~km}^{2}$ and 1/10.6 $\left(5.4^{\circ}\right)$, respectively, for the main river and approximately $0.5 \mathrm{~km}^{2}$ and $1 / 6.3\left(9.0^{\circ}\right)$, respectively, for the left tributary. A gentle slope terrain spreads with the peak at $409 \mathrm{~m}$ above sea level, and the valley's bottom was filled with sediments characterized by a relatively wide valley. The geological bedrock composition is mainly Cretaceous Kitakami granites.

Based on comparisons with existing aerial photographs and field survey results, the number of affected houses was estimated to be eight. Three houses were affected by sediment runoff from the main river, and five houses were affected by sediment and driftwood runoff from the left tributary. For some damaged houses on the left tributary, it appeared that the debris flows flooded the gentle slope section downstream of the valley exit, directly hit the houses, and then flowed out (Fig. 5b). According to the results of interviews with local residents, these people had found refuge in the evacuation shelter the day before the sediment movement occurred at the request of the president of the local residents' self-government association; as a result of this early evacuation, no human casualties occurred.

The sediment production and movement for the main river and the left tributary, respectively, were as follows. Although the volume of sediment transport from the main river was smaller than that of the left tributary, as described later, sediment and driftwood produced from the river banks through erosion flowed out and houses were damaged (Fig. 5). The width of the river that used to be located upstream of the houses was approximately $3 \mathrm{~m}$ before the Typhoon. The channel direction had been artificially altered and attached to the downstream channel, but evidence showed that this bent portion was blocked with driftwood to a height of approximately $2 \mathrm{~m}$ above the riverbed. It was presumed that the blockage was breached and stones with an average diameter of approximately $30 \mathrm{~cm}$, as well as driftwood, directly flowed into the houses, causing destruction. The observation of the ground underneath the foundation concrete of the damaged houses revealed that it consisted of mixed materials, and sub-angular gravels had an average diameter of approximately $20 \mathrm{~cm}$, as shown in Fig. 6a. This was considered an alluvial cone formed by the past runoff and sedimentation. The 

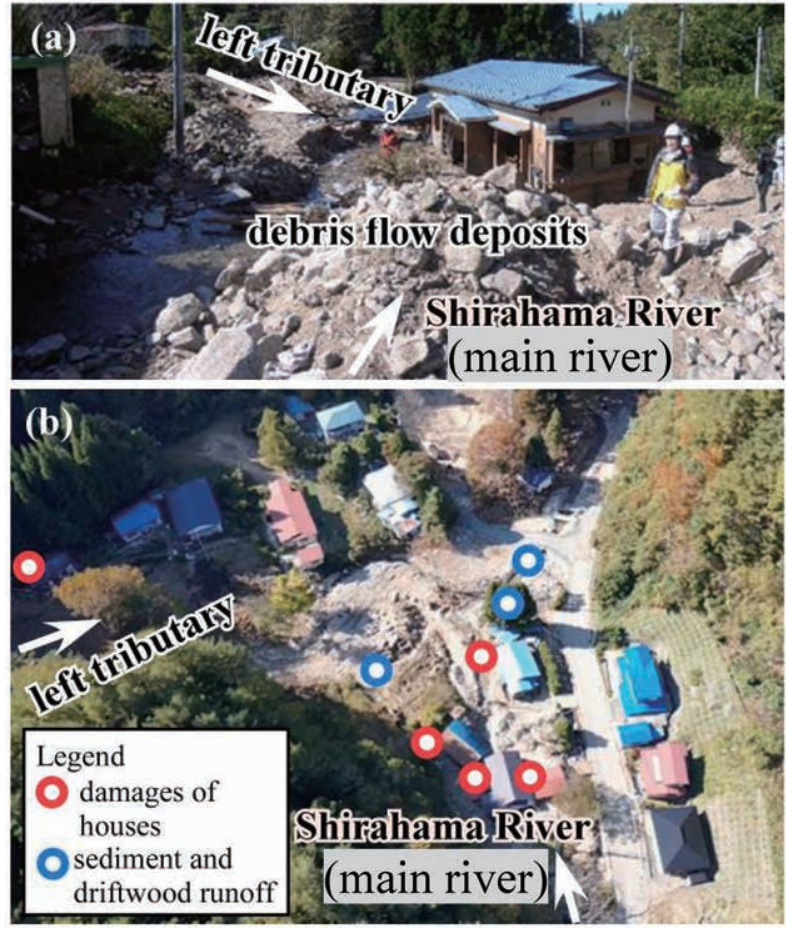

Fig.5 Damages and areal extent of debris flow ((a) Damages of houses, (b) Areal extent of debris flow near the houses)

affected houses were built on this alluvial cone.

In the left tributary, a section where sediment transport path was clearly traced by the field reconnaissance and an unmanned aerial vehicle (UAV); no slope collapse was observed. However, scree from erosion of past debris flow deposits and slope cliffs deposited on the benches and beds were observed everywhere. Considering such local conditions, it was presumed that the debris that flowed out during the event gradually eroded pre-existing slopes and channel bed sediments because of increased flow discharge as a result of heavy rain, transported coarse- and fine-grained sediment, and exacerbated flooding downstream. At points where the channel width and bed gradient changed, the bed rose by more than $2 \mathrm{~m}$ because of sedimentation and driftwood was deposited in the gorge section and intertwined with the tree onshore (Fig. 6b). Where the bank was eroded, the tree roots remained, as if they had been pulled downstream. It was presumed that the trees that had grown near the channel bed flowed downstream as driftwood.

\subsection{Mawakura area in Marumori Town, Miyagi Prefecture}

The area is underlain by granodiorite with spheroidally weathered corestones with major diameters of $1 \mathrm{~m}$ to several meters contained in the weathered soil layer above the bedrock. Besides, above the soil layer, brown forest soil is presence with a
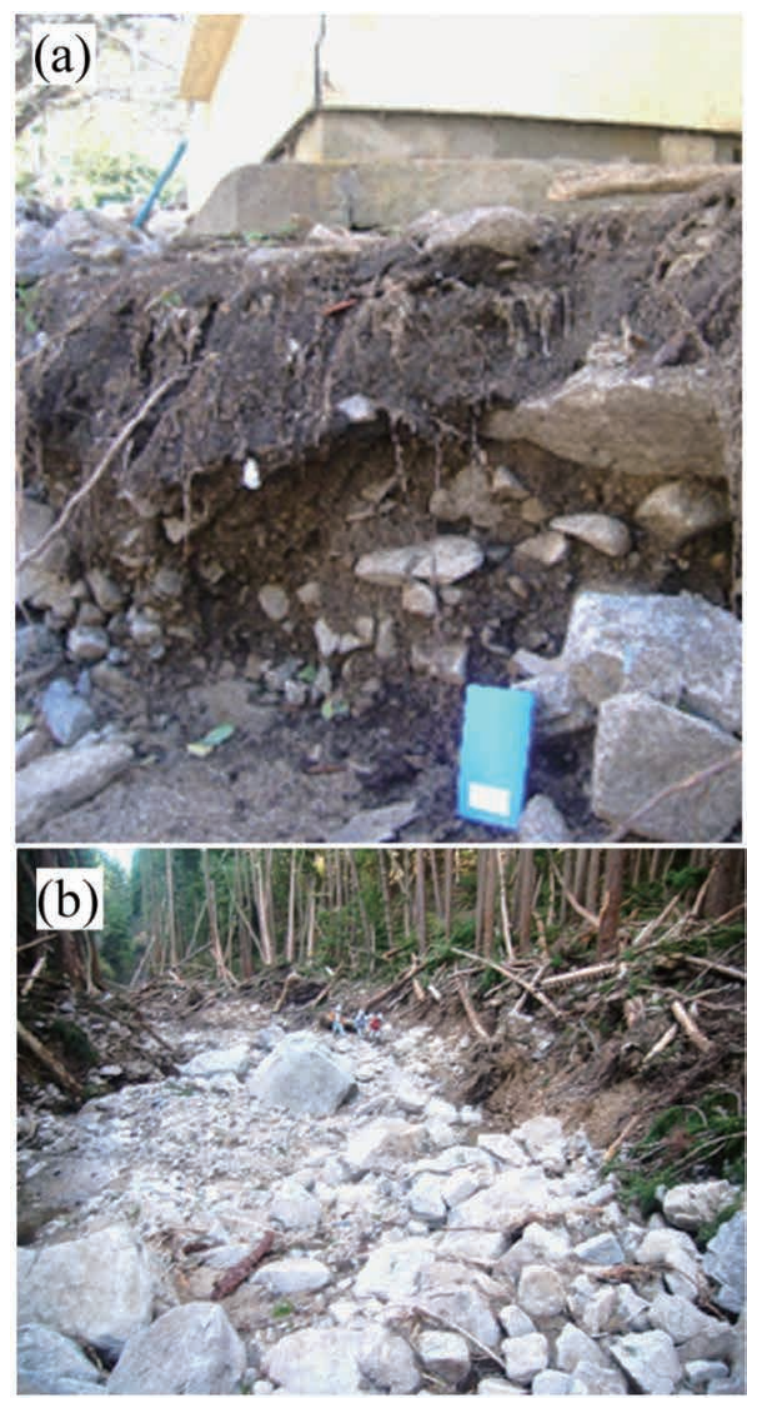

Fig.6 Debris flow observed at Shirahama area, Miyako City ((a) Destructed basement of a damaged house, (b) Deposition of debris flow and woody debris)

thickness of approximately 20 to $40 \mathrm{~cm}$ (Fig. 7). Interpretation of Google Earth imagery (of 2009 and 2018) before the landslide and onsite laser measurement suggest that the gradient of the landslide was approximately $15^{\circ}$ to $35^{\circ}$. The location that included the landslide inception site and landslide downward flow area was in a cedar plantation. The cedar tree height at the landslide area's margin was approximately 10 to $15 \mathrm{~m}$, and the breast-height diameter was 10 to $20 \mathrm{~cm}$. In this area, multiple shallow landslides occurred on the slopes near the ridgeline (at an elevation of $288-330 \mathrm{~m}$ ), and the landslides flowed down while encompassing the cedar plantation trees in their path. At the sites where the shallow landslides occurred and proceeding downward, almost all planted trees were swept away. From an altitude of $214 \mathrm{~m}$, where the slope became gentle, the flow direction turned to the left, and flooding and 


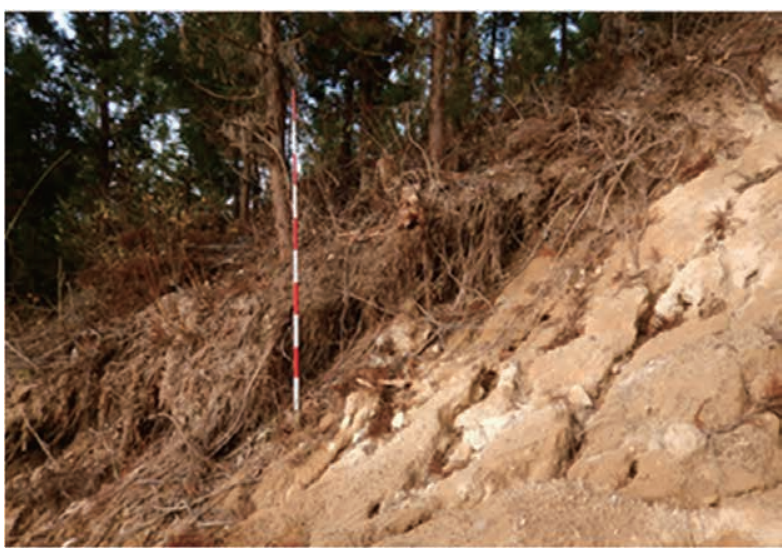

Fig.7 Bedrock of granodiorite, overlain by weathered soil observed at a landslide

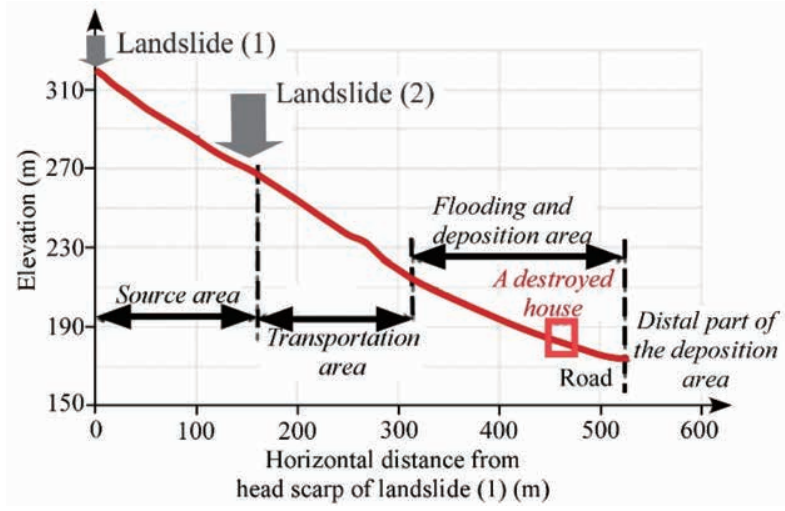

Fig.8 Longitudinal profile of the landslide showing the source, transportation, and deposition areas

sedimentation occurred. As a result, a wooden twostory house at a horizontal distance of approximately $450 \mathrm{~m}$ from the highest point of the collapsing landslide (scarp) was swept from its foundation (resulting in four human victims) and flooding and sedimentation occurred over the road directly downstream of it. The horizontal distance from the uppermost point in the scarp to the lowest tip of the sediment was approximately $530 \mathrm{~m}$ (Fig. 8), and the equivalent friction coefficient was approximately 0.28 .

The most upstream landslide occurred on a hillside slope (slope of approximately $35^{\circ}$ ) and exhibited a valley topography just below the ridge, with a width of approximately $20 \mathrm{~m}$, length of approximately $40 \mathrm{~m}$, and average depth of approximately $1.0 \mathrm{~m}$ (hereafter referred to as 'landslide (1)') (Fig. 9a). Moreover, immediately downstream of landslide (1), a landslide with a width of approximately $80 \mathrm{~m}$, length of approximately $20 \mathrm{~m}$, and average depth of approximately $0.5 \mathrm{~m}$ (hereafter called 'landslide (2)') was located on the hillside slope (slope $15^{\circ}$ to $20^{\circ}$ ) directly below the left ridgeline (this is thought to be a topography formed as a result of multiple landslide occurrence) (Fig. 9b). On the scarps of landslide (1)
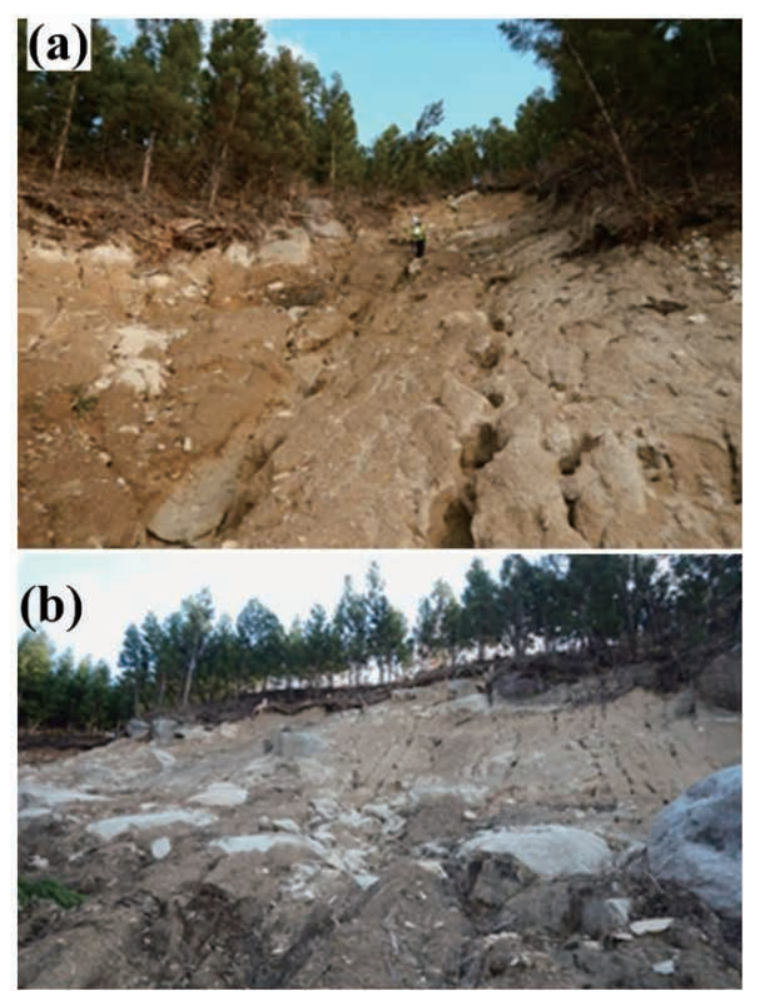

Fig.9 Photographs of landslides ((a) Landslide (1), (b) Landslide (2))

and (2), it was assumed that several pipe holes with a major axis of tens of centimeters may have formed in the forest soil layer immediately above the base rock, granodiorite, causing the piping failure.

The total amount of sediment yielded from landslide (1) and (2) was approximately $2000 \mathrm{~m}^{3}$ (including voids). Many corestones flowed out, along with fine sediments, such as clay, silt, sand, and gravel, because of the collapse and were deposited in the transportation and flooding and deposition areas. Part of the corestones were exposed on the slope surface after the slope failure; however, many corestones remained buried in the ground.

In the section between the area immediately below landslide (2) (altitude of $266 \mathrm{~m}$ ) and the area $137 \mathrm{~m}$ away in the horizontal direction (altitude of $213 \mathrm{~m}$ ), debris originated from landslide (1) and (2) flowed downward with a width of about $15 \mathrm{~m}$, and the trees and driftwood that fell but were not washed away piled up on the edge in the longitudinal direction. At the middle part of the sediment transportation area, bedrock, that was overlain by sediment deposits of 22.5-m wide and 2-3.0-m deep over a horizontal distance of $130 \mathrm{~m}$, was exposed. It was thought that the water generated by the piping failure (spouting from pipe holes of the previously mentioned scarp) eroded the forest soil on the surface layer and the weathered soil layer immediately below it after the landslide. The volume of sediment yielded from this 

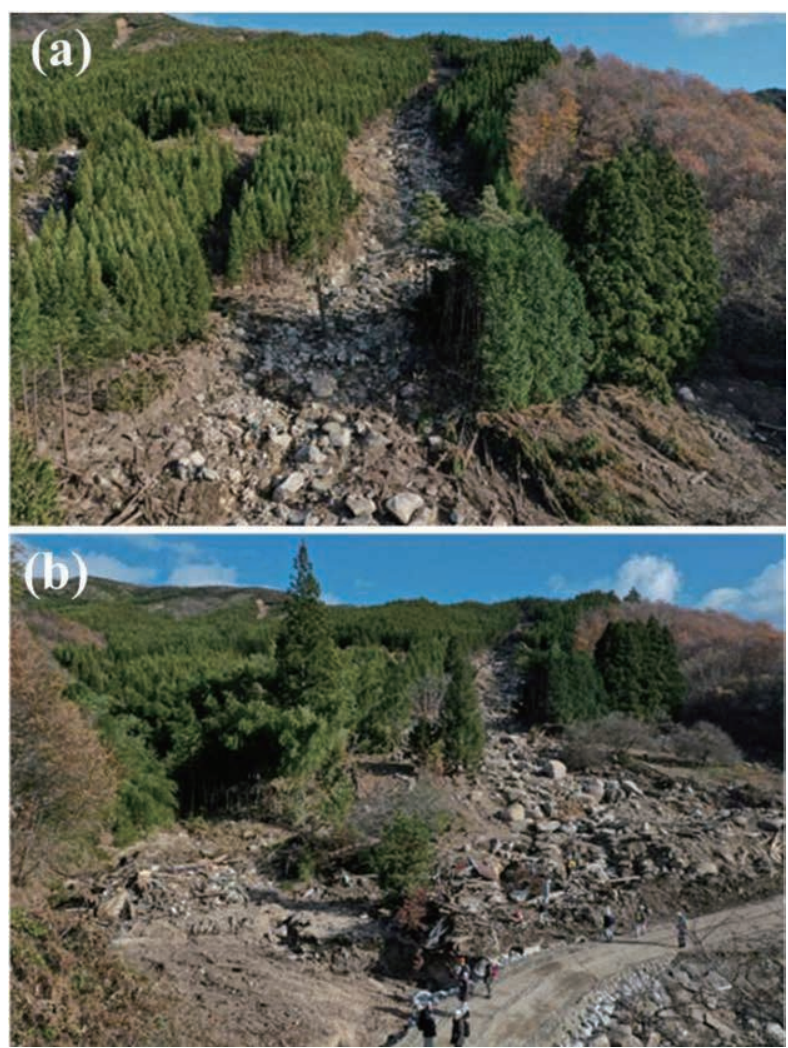

Fig.10 Topography observed at the transportation and deposition areas ((a) Transportation, (b) Sediment deposition)

section was approximately $700 \mathrm{~m}^{3}$ (including voids).

Sediment and driftwood flooded and accumulated in the section (with a gradient of approximately $11^{\circ}$ ) from the end of the downward flow locations to the top of the sediment in the horizontal direction of approximately $200 \mathrm{~m}$. The maximum width of the sediment path and deposition was approximately $70 \mathrm{~m}$ upstream of the road. The flow depth of sediment near the end of the field of downward flow was estimated to be approximately $2 \mathrm{~m}$ from traces of the detachment of cedar bark remaining in the vicinity. In the area of sediment flooding and sedimentation, many corestones were near the sedimentation surface and is considered to have flowed down from the upstream area (Fig. 10 b). The sediment thickness along the road around the flow-damaged houses was approximately 1.5 to $2.0 \mathrm{~m}$. The cross-section observation of the deposited sediment showed no obvious stratification, and it was clear that core stones, gravel, sand, etc., were mixed (core stones are often found near the surface of sediments). It is possible that flooding and sedimentation occurred in a turbulent state in the flow direction (Fig. 10b).

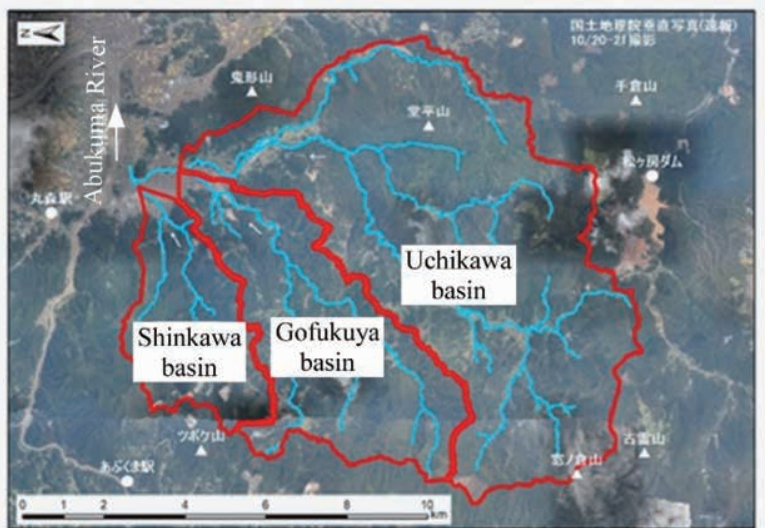

Fig.11 Drainage area of the Shinkawa River (The vertical photo after Geospatial Information Authority of Japan, 2019))

\subsection{Shinkawa basin in Marumori Town, Miyagi Prefecture}

The Shinkawa basin originates at the prefectural border between the town of Marumori in Miyagi Prefecture and Date City in Fukushima Prefecture. The Shinkawa River merges with the Uchikawa River, flows through the center of the Town of Marumori, and merges with the Abukuma River (Fig. 11). The river basin area was approximately $16.9 \mathrm{~km}^{2}$, the channel length was approximately $6.8 \mathrm{~km}$, and the average mountain gradient was approximately $1 / 17$ $\left(3.4^{\circ}\right)$. Downstream of the lizuka area, there was a relatively gentle topography where houses and other buildings requiring protection were distributed and where flood damage had occurred in the past (1986, 1989, 1999, and 2002). The geology is mainly underlain by granite or granodiorite, and this was covered with colluvial, fluvial and alluvial sediments distributed in swamps and valleys. In the basin, there are five erosion control dams, one groundsill, and one small check dam. The debris flow occurrence time was estimated at $0: 00$ to $1: 00 \mathrm{am}$ on October 13, based on the results of interviews with residents (Fig. 4).

As a result of the field survey and aerial photo interpretation, it was confirmed that sediment and flooding caused damage to approximately 250 houses, Prefectural Road 101 (the Marumori Yanagawa Road), and Prefectural Road 45 (the Marumori Reizan Road). Sediment and driftwood accumulation and blockage occurred at bridges with a narrow downflow section, and it is possible that this effect caused sedimentation and flood inundation over a wide area (Fig. 12a).

An example of a landslide at the upper reaches of Shinkawa River is shown in Fig. 12b. The landslide reached a length of about $30 \mathrm{~m}$, which the width is of $10 \mathrm{~m}$. The landslide occurred just below the slope break and in a zero-order basin. The landslide exposed weakly weathered granodiorite, decomposed granite soil (Masa soil) containing corestones on the collapsed 


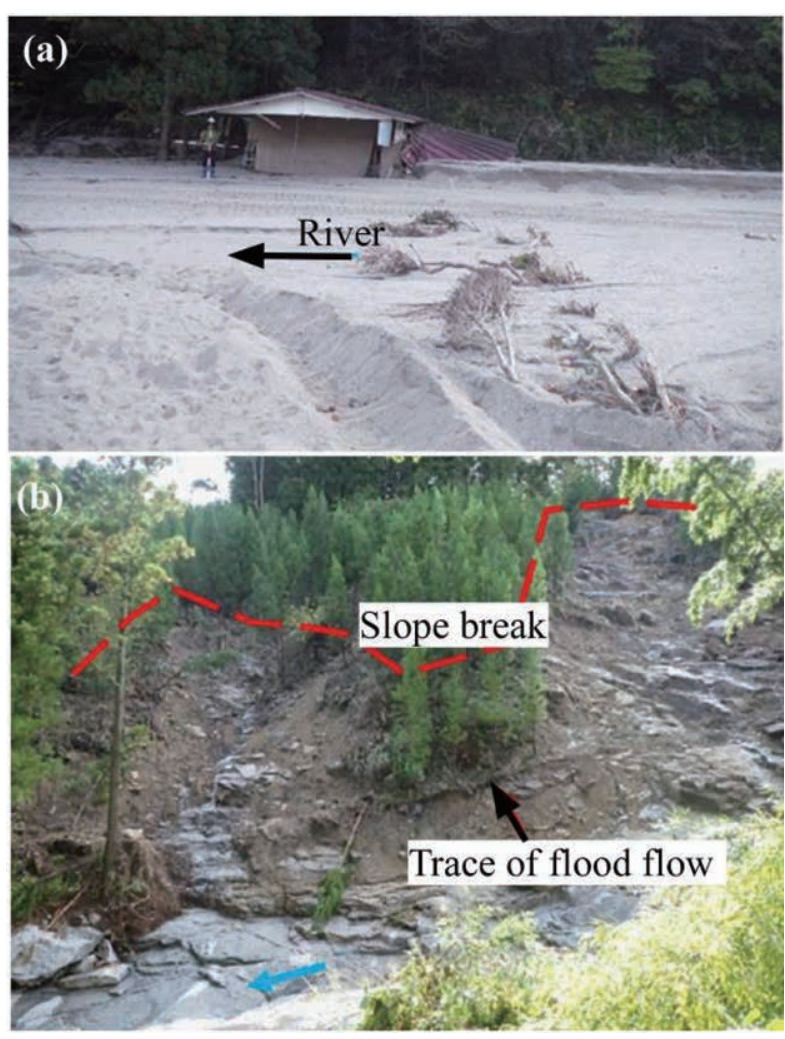

Fig.12 Sediment disaster in the Shinkawa River ((a) A house buried by sediment and flood disasters, (b) An example of a landslide)

area's edge, and colluvial soil. Besides, traces of flood flow below the collapsed area, pipe hole with a diameter of approximately $0.3 \mathrm{~m}$, loose slope for the surrounding area, and open cracks accompanying with step-like features at the slope's top were observed. Many landslides with similar characteristics were found along the stream.

Based on the preceding observational results, the mechanism of the landslide occurrence was assumed to be as follows. In normal rainfall, the rainwater permeated the earth and sand (extensively weathered granite) in the zero-order basin and flowed out as a shallow groundwater flow. However, because of the continuous rainfall of $427 \mathrm{~mm}$, which had never been experienced in the basin, rainfall saturated all layers of the weathered granite (Masa soil, including core stones) in the zero-order basin and upper colluvium. It was thought that the lower part of the zero-order basin flowed out because of lateral erosion of the main river; the upper slope became unstable, and the pore water pressure at the boundary between the bedrock and the upper Masa soil or colluvium layer rose. It was also assumed that the shear plane was formed at the boundary, and the Masa and colluvial soil layers collapsed. A large number of landslide occurred on slopes (composed with Masa soil and thick layers of colluvial soils) that had not collapsed in past rainfall, and riverbed and riverbank erosion also occurred. It was thought that a large amount of sediment and driftwood caused sediment flooding and formed a flat valley floor.

\section{SUMMARY}

As a result of Typhoon No. 19, 501 and 952 sediment disasters have been reported in the Tohoku region and nationwide, respectively, as of December 24, 2019 [Ministry of Land, Infrastructure, Transport and Tourism, 2019]. The number of the sediment disaster is the largest since 1982. Here, we reported the survey results as observed in the Shirahama area, Miyako City in Iwate Prefecture and the Mawakura area and Shinkawa basin, Marumori Town in Miyagi Prefecture.

The survey results can be summarized as followings: (1) slope failures were distributed in the weathered granitic rocks, (2) the slope failures were shallow and no large-scale landslides were triggered, and (3) main sediment sources are related to the rework of sediments of past debris-flow activity stored in channels and bank erosion. Besides, in the Tohoku region, many slopes are not accustomed to torrential rain, as demonstrated by Typhoon No. 10 in 2016 [Irasawa et al., 2017], which landed for the first time from the Pacific Ocean side of the Tohoku region since the Japan Meteorological Agency started recording statistics. It is presumed that sediment runoff is prone to occur when mountain stream flow increases like this event.

ACKNOWLEDGMENT: We would like to express our gratitude to the Tohoku Regional Bureau of the Ministry of Land, Infrastructure, Transport and Tourism; the Tohoku Forest Management Bureau; and Iwate, Miyagi, and Fukushima Prefectures for their considerable kindness when we conducted the field survey. The authors also thank Yoichi Makino, Yuki Koga, Chizuru Toya (Asia Air Survey), and Yoshiharu Ishikawa (Faculty of Agriculture, Tokyo University of Agriculture and Technology), who accompanied the field survey and provided advice. We pray for the affected area's speedy restoration and reconstruction.

\section{REFERENCES}

Irasawa, M., Higaki, D., Koiwa, N., Takahashi, M., Okamoto, T., Yasuno, M., Tada, N., Nakajima, T., Arai, M., Ochiai, T., Kasahara, R., Saito, A., Sato, S., Hirose, S., Koubu, M., Sato, T., Ootsubo, S., and Makabe, S. (2017) : Sediment disasters caused by Typhoon No. 10 on August 30, 2016 in Iwaizumi town and Miyako city, Iwate, Japan Society of Erosion Control Engineering, Vol. 60, No. 6, pp. 71-79 (in Japanese, with English Abstract). 
Irasawa, M., Matsuo, S., Arai, M., Kaibori, M., Tsou, C. -Y., Yamada, T., Kasai, M., Koi, T., Kato, N., Wakahara, T., Higaki, D., Ikeda, H., Ishikawa, Y., Arai, K., Hirose, S., Sato, T., Kawatabata, H., Koubu, M., Niwa, N., Sugawara, K., Matsusaka, H., Tada, N., and Kon, T. (2020) : Sediment disasters caused by Typhoon Hagibis on October, 2019 in Tohoku region, Japan Society of Erosion Control Engineering, Vol. 72, No. 6, pp. 42-53 (in Japanese, with English Abstract).

Geospatial Information Authority of Japan (2019): Aerial images about the Typhoon No. 19 in 2019 (vertical aerial image (quick report), oblique aerial image, and orthorectified aerial image (quick report)). Available at https : //www.gsi.go.jp/BOUSAI/R1.taihuu19gou.html (in Japanese). Accessed 2020-01-26.

Japan Meteorological Agency (2020) : Quick report on heavy rainfall, storm and etc. of the Typhoon No. 19 during $10^{\text {th }}$ to $13^{\text {th }}$ October, Available at https : //www.data.jma.go.jp/obd/ stats/data/bosai/report/2019/20191012/jyun_sokuji 20191010 -1013.pdf (in Japanese). Accessed 2020-01-27.

Ministry of Land, Infrastructure, Transport and Tourism (2019) :
Press Announcement: Sediment disaster induced by the Typhoon No. 19-the number of the sediment disaster hit a record high. Available at http : //www.mlit.go.jp/report/press/ content/001321288.pdf (in Japanese). Accessed 2020-01-27.

Irasawa, M., Higaki, D., Koiwa, N., Takahashi, M., Okamoto, T., Yasuno, M., Tada, N., Nakajima, T., Arai, M., Ochiai, T., Kasahara, R., Saito, A., Sato, S., Hirose, S., Koubu, M., Sato, T., Ootsubo, S., and Makabe, S. (2017) : Sediment disasters caused by Typhoon No. 10 on August 30, 2016 in Iwaizumi town and Miyako city, Iwate, Japan Society of Erosion Control Engineering, Vol. 60, No. 6, pp. 71-79 (in Japanese, with English Abstract).

Japan Meteorological Agency (2020) : Quick report on heavy rainfall, storm and etc. of the Typhoon No. 19 during $10^{\text {th }}$ to $13^{\text {th }}$ October, Available at https : //www.data.jma.go.jp/obd/ stats/data/bosai/report/2019/20191012/jyun_sokuji 20191010 -1013.pdf (in Japanese). Accessed 2020-01-27.

Received : 4 February 2020

Accepted : 15 April 2020 